\title{
Search for evidence by medical residents in Trujillo, Peru
}

\author{
Miguel Tresierra-Ayala* and Carlos Pinco-Cabanillas \\ Facultad de Medicina de la Universidad Nacional de Trujillo, Trujillo, Peru
}

\begin{abstract}
Objective: The objective of the study was to describe the use of scientific evidence in the clinical practice of resident physicians. Materials and methods: A total of 284 physicians were interviewed at hospitals in Trujillo, Peru. Results: Resident doctors attend an average of 22 cases/day; they asked 0.35 questions per case and sought answers at a rate of 0.4 per question. The main reason for not looking for answers was a lack of time; the internet was the main source of information, and the main obstacle was payment for selected information. The participants consider that their clinical practice and that of their teachers are evidence based no more than $50 \%$ of the time. Conclusions: Resident physicians participating in the study practice evidence-based medicine; however, they find it difficult to perform correctly due to economic factors related to access to information and workload.
\end{abstract}

Key words: Scientific evidence. Medical residency. Medical information. Trujillo.

\section{Introduction}

During their professional careers, physicians face multiple dilemmas and situations of uncertainty, these situations create variability in the clinical practice, and they complicate decision-making in managing patients. ${ }^{1-3}$ In response to these problems, evidence-based medicine (EBM) was created, contributing a conceptual frame for the resolution of clinical problems and bringing clinical research data closer to medical practice $^{2,4,5}$.

The traditional paradigm of medical practice was based on authority, non-systemic clinical observation, and studying basic mechanisms of the illness ${ }^{6,7}$, whereas the new paradigm proposes the search and selection of better scientific evidence for the resolution of problems of everyday medical practice ${ }^{8-10}$. Sackett defines EBM as the "conscious, explicit, and sensible use of the better available evidence for decision-making in the care of an individual patient"11. This concept, although with a background from the $19^{\text {th12 }}$ century, has modified the medical paradigm in patient care ${ }^{13,14}$.

The incorporation of EBM in developing countries with reduced economic and technological capacity has added new difficulties to its practice ${ }^{15-17}$. Within this contextual framework, the present work is aimed at describing evidence-based medical practices and their difficulty in practice in resident physicians in a developing country.

\section{Materials and methods}

A transversal study was conducted in the years 2017 and 2018 among resident physicians studying for their second medical specialty in hospitals in Trujillo. From

\section{Correspondence:}

${ }^{*}$ Miguel A. Tresierra-Ayala

E-mail: mtresierra@medicos.com
Available online: $17-03-2020$

Date of reception: 11-08-2019

Date of acceptance: 12-12-2019 DOI: 10.24875/RMU.19000119
Medicina Universitaria. 2020;22(1):10-14 www.medicinauniversitaria.org (http://creativecommons.org/licenses/by-nc-nd/4.0/). 
the 327 enrolled students, a total of 289 resident physicians who voluntarily accepted to participate in the study were surveyed. Five questionnaires were eliminated since they were highly incomplete and with some sort of note referring to the fact that they could not respond due to an excess of work, 26 residents were conducting studies in different hospitals out of town or abroad, and 12 physicians did not agree to participate in the study. All physicians conducted their studies in the four hospitals with the highest level of complexity in the city of Trujillo, two of them belonging to the Ministry of Health and the other two to the social health insurance system.

The instrument created for data collection was a survey drafted by the authors (Annex), based on previously conducted works ${ }^{15,18}$. The questionnaire was validated by four physicians and a professor, teachers at the National University of Trujillo, using indicators and charts by Escobar-Perez and Cuervo-Martinez ${ }^{18}$, modified by Galicia et al. ${ }^{19}$ to validate its contents by expert judgments, obtaining a Kappa of 0.91 .

In search of reasons to not find evidence, sources of information, tools, or difficulties, open questions were made to obtain information from the physicians who had more than one answer to a specific question.

Results were presented in simple charts with absolute and relative frequencies and with a Chi-square statistical analysis application to measure differences in averages.

\section{Results}

The general responses of the 284 resident physicians are shown in table 1 . The respondents were majority male with $62 \%$ but without a statistically significant difference between residents of clinical or surgical specialties. Concerning the question about the proportion of their clinical practice (their own and that of their assistant), that was evidence based, a difference between the averages was found, being more significant in the resident physician than the assistants.

The reasons as to why we did not look for an answer are listed in table 2. The question was open ended to be able to accept that the resident physician could have more than one reason not to apply EBM. A total of 483 answers were obtained. Lack of time was the obstacle with the most significant importance in $41 \%$ of them; smaller percentages were lack of resources with $11 \%$, lack of interest with $10 \%$, tiredness $8 \%$, and simple and repeated cases with $8 \%$.
Table 1. General characteristics of resident doctors, Trujillo, 2017 ( $\mathrm{n}=284$ )

\begin{tabular}{|l|c|c|c|}
\hline Characteristic & $\mathbf{n}$ & $\%$ & $\mathbf{p}$ \\
\hline $\begin{array}{l}\text { Gender } \\
\text { Male }\end{array}$ & 176 & 62 & 0.000 \\
\hline Female & 108 & 38 & \\
\hline $\begin{array}{l}\text { Area of study } \\
\quad \text { Doctor }\end{array}$ & 152 & 53.5 & 0.58 \\
$\quad$ Surgeon & 132 & 46.5 & \\
\hline $\begin{array}{l}\text { Clinical practice based on evidence } \\
\text { Resident doctor }\end{array}$ & & & \\
$\quad$ Assistant doctor & & 54.21 & 0.0041 \\
\hline
\end{tabular}

Table 2. Reasons why the resident doctor did not seek an answer to the questions raised $(n=483)$

\begin{tabular}{|l|c|c|}
\hline Reason & $\mathbf{n}$ & $\%$ \\
\hline Lack of time & 196 & 41 \\
\hline Lack of resources & 52 & 11 \\
\hline Lack of interest & 50 & 10 \\
\hline Tired & 39 & 8 \\
\hline Simple or repeated cases & 37 & 8 \\
\hline Cost & 23 & 5 \\
\hline Resolved by a supervisor & 23 & 5 \\
\hline Forgot & 20 & 4 \\
\hline Did not know the language & 4 & 1 \\
\hline Other & 39 & 8 \\
\hline
\end{tabular}

The questions aimed at the search for information are shown in table 3. To inquire about information sources, an open-ended question was included as well. While scientific articles had the highest percentage of evidence sources at $35 \%$, it draws attention to the fact that non-scientific internet sources reached $32 \%$. The most utilized tool was PubMed with $17 \%$, with free access to the Medline database of bibliographic references and summaries of biomedical research articles, next was Google $15 \%$ and UpToDate $12 \%$. The main difficulty in the search was the need for payment to access scientific information (52\%), understanding a non-native language $(15 \%)$, an abundance of irrelevant information $(15 \%)$, and difficulty using search engines (10\%).

\section{Discussion}

Our residents present an average daily workload of 21 patients attended. Yale University reports a workload of six patients daily for each physician ${ }^{20}$. 
Table 3. Search for information by resident doctors to solve their questions

\begin{tabular}{|c|c|c|}
\hline Description & $\mathbf{n}$ & $\%$ \\
\hline $\begin{array}{l}\text { Source of information }(n=525) \\
\text { Articles } \\
\text { Non-scientific internet } \\
\text { Texts } \\
\text { Questions to tutor } \\
\text { Questions to partner } \\
\text { Other }\end{array}$ & $\begin{array}{c}183 \\
166 \\
84 \\
49 \\
35 \\
8\end{array}$ & $\begin{array}{c}35 \\
32 \\
16 \\
9 \\
7 \\
2\end{array}$ \\
\hline $\begin{array}{l}\text { Tools used ( } \mathrm{n}=1074) \\
\text { PubMed } \\
\text { Google } \\
\text { UpToDate } \\
\text { Clinical guides } \\
\text { Medline } \\
\text { Cochrane library } \\
\text { Hinari } \\
\text { Online journals } \\
\text { eMedicine } \\
\text { Other }\end{array}$ & $\begin{array}{c}179 \\
157 \\
124 \\
121 \\
114 \\
111 \\
60 \\
52 \\
30 \\
126\end{array}$ & $\begin{array}{l}17 \\
15 \\
12 \\
11 \\
11 \\
10 \\
6 \\
5 \\
3 \\
12\end{array}$ \\
\hline $\begin{array}{l}\text { Difficulties ( } n=373 \text { ) } \\
\text { Payment for select information } \\
\text { Language } \\
\text { Much irrelevant information } \\
\text { Difficulty with search engines } \\
\text { No internet access } \\
\text { Little local information }\end{array}$ & $\begin{array}{c}195 \\
68 \\
55 \\
40 \\
14 \\
3\end{array}$ & $\begin{array}{c}52 \\
18 \\
15 \\
10 \\
4 \\
1\end{array}$ \\
\hline
\end{tabular}

This significant difference justifies the fact that $41 \%$ of resident physicians claim that they did not have time to respond the questions presented, a reason also reported by other researchers ${ }^{21-24}$, this workload of residents results in fatigue, increased sleep, stress, and lack of motivation ${ }^{25,26}$, which negatively influences their care performance and academic activities.

The residents in our study asked 3.5 questions for every ten patients; in Yale ${ }^{20}$, residents asked seven questions for every 10 patients. In both cases, questions were unanswered due to a lack of time, also reported at the University of Southampton ${ }^{22}$. Another study at the University of Missouri reports that resident doctors have an obstacle that the search is not fast enough ${ }^{27}$. Although the lack of time could also be understood as an explanation, the difference could be due to the fact that these studies ${ }^{20,22,27}$ were made 20 years before our study. However, the current studies do not differ from ours because they also referred to a lack of time as an obstacle 23,24 .

In 2015, in an EBM Implementation Program in Kazakhstan, $44 \%$ of doctors said that they did not answer the questions, and in terms of obstacles, in $62 \%$, it was the difficulty of bringing the principles of EBM to the practice and "commitment to traditional, obsolete methods of treatment"28. A study in Peru found that the incomplete use of EBM is explained by an inappropriate concept and that the main obstacle is "the poor promotion of EBM"29.

Scientific medical information is searched for in original articles in $35 \%$ of consultations, coinciding with studies in England ${ }^{22}$ and the US ${ }^{20}$ that refer to searching original articles $30 \%$ of the time. Other sources of information are similar to our findings including textbooks and questions to attending physicians or other resident colleagues.

PubMed is the most used search engine. In international studies, the search varies by time and country ${ }^{30}$. Our results show that the resident physician mostly uses free literature, different from what was reported in a study that says that $62 \%$ of searches used a personal subscription ${ }^{30}$.

Another difficulty in accessing information is the language of publication, which represents a clear disadvantage for Latin American doctors. According to Sierra-Galán ${ }^{31}$, the percentage of health professionals who speak English is very small and this conditions them to access literature in Spanish that is not necessarily "cutting edge." Plus, $98 \%$ of studies published on PubMed are in English ${ }^{32}$. In Peru, Mejía et al. ${ }^{33}$ estimated that only $30 \%$ of graduates with a medical degree during recent years were fluent in English. This reason, plus the lack of time for the doctor and the costs, means that the resident physician generally only searches for information in Spanish, which does not necessarily reach the highest level of evidence and does not include the opinion of international consensus ${ }^{30}$.

\section{Conclusions}

Resident physicians in the hospitals of the city of Trujillo, Peru, use EBM in only half of their clinical practice. The difficulties lie in the excess of the number of patients, which create a lack of time for analysis, in addition to the costs of access to scientific information, lack of knowledge of the language, and difficulties in the use of search engines.

\section{Conflicts of interest}

The authors declare that they have no conflicts of interest. 


\section{Ethical disclosures}

Protection of human and animal subjects. The authors declare that no experiments were performed on humans or animals for this study.

Confidentiality of data. The authors declare that they have followed the protocols of their work center on the publication of patient data.

Right to privacy and informed consent. The authors declare that no patient data appear in this article.

\section{References}

1. Castellanos-Olivares A, Vásquez-Márquez P. ¿Qué es la medicina basada en evidencias? Rev Mex Anestesiol. 2016;39:236-9.

2. Céniga MV, Allegue-Allegue N, Bellmunt-Montoya S, López-Espada C, Riera-Vázquez R, Solanich-Valldaura T, et al. Medicina basada en la evidencia: concepto y aplicación. Angiología. 2009;61:29-34.

3. Muñoz F, Cabrera F. Reflexiones sobre la evidencia en medicina. Rev Med Chil. 2005:133:1252-7.

4. Junquera L, Baladrón J, Albertos J, Olay S. Medicina basada en la evidencia (MBE). Ventajas. Rev Esp Cir Oral Maxilofac. 2003;25:265-72.

5. Brito G, González A, Cruz P. Origen evolución y reflexiones sobre la medicina basada en la evidencia. Rev Cubana Cir. 2010;49:(2).

6. Legón M, Vega N, Brito L. El paradigma médico social y la competencia comunicativa del profesional de ciencias médicas. Rev Haban Cienc Méd. 2010:9:433-40.

7. Camejo L, Valdés I. Sociedad y medicina: paradigmas médicos en las coordenadas de la modernidad. Panor Cuba Salud. 2016;11:40-6.

8. Patiño JF. Paradigmas y dilemas de la medicina moderna en el contexto de la atención gerenciada de la salud. Medicina. 2001;23:163-78.

9. Guyatt G, Rennie D, Meade MO, Cook DJ. American Medical Association. In: User's Guide to the Medical Literature. Essentials of Evidenced Medicine Clinical Practice. $2^{\text {nd }}$ ed. San Francisco: McGraw-Hill; 2002.

10. Hernández-Girón C, Orozco-Núñez E, Arredondo-López A. Modelos conceptuales y paradigmas en salud pública. Rev Salud Pública. 2012;14:315-24.

11. Sackett DL, Richardson WS, Rosenberg W, Haynes RB. Evidence Based Medicine: how to Practice and Teach EBM. $2^{\text {nd }}$ ed. Edinburgh: Churchill Livingstone; 2000. Available from: https://www.bmj.com/content/313/7069/1410.1.full.

12. Lip C. El paradigma indiciario en la medicina. Rev Med Hered. 2001;12:65-74

13. Biagini L. La evidencia y el proceso de toma de decisiones. Rev Méd Chil. 2005;133:871-3.

14. Lam R, Oliva M, Hernández $P$, Milanés M. Medicina basada en la evidencia. Rev Cubana Hematol Inmunol Hemoter. 2002;18:(3). Available from: http://www.scielo.sld.cu/scielo.php?script=sci_arttext\&pi$\mathrm{d}=\mathrm{s}$ 0864-02892002000300002\&lng=es.

15. Ely JW, Osheroff JA, Ebell MH, Bergus GR, Levy BT, Chambliss ML, et al. Analysis of questions asked by family doctors regarding patient care. BMJ. 1999;319:358-61.
16. Ely JW, Osheroff JA, Ebell MH, Chambliss ML, Vinson DC, Stevermer JJ, et al. Obstacles to answering doctors' questions about patient care with evidence: qualitative study. BMJ. 2002;324:710.

17. Ely JW, Osheroff JA, Chambliss ML, Ebell MH, Rosenbaum ME. Answering physicians' clinical questions: obstacles and potential solutions. J Am Med Inform Assoc. 2005;12:217-24.

18. Galicia L, Balderrama J, Edel R. Validez de contenido por juicio de expertos: propuesta de una herramienta virtual. Apertura. 2017;9:42-53.

19. Escobar-Pérez J, Cuervo-Martínez A. Validez de contenido y juicio de expertos: una aproximación a su utilización. Av Med. 2008;6:27-36.

20. Green ML, Ciampi MA, Ellis PJ. Residents' medical information needs in clinic: are they being met? Am J Med. 2000;109:218-23.

21. Coumou HC, Meijman FJ. How do primary care physicians seek answers to clinical questions? A literature review. J Med Libr Assoc. 2006;94:55-60.

22. McColl A, Smith H, White P, Field J. General practitioner's perceptions of the route to evidence based medicine: a questionnaire survey. BMJ. 1998:316:361-5

23. Del Fiol G, Workman TE, Gorman PN. Clinical questions raised by clinicians at the point of care: a systematic review. JAMA Intern Med. 2014; $174: 710-8$

24. Brassil E, Gunn B, Shenoy AM, Blanchard R. Unanswered clinical questions: a survey of specialists and primary care providers. J Med Libr Assoc. 2017:105:4-11.

25. Díaz LA, Arab JP, Cotoras P, Lagos DV, Carreño MB, Rojas V, et al. Evaluación de la carga laboral en residentes chilenos de especialidades y subespecialidades médicas. ARS Rev Cienc Méd. 2016;41:13-20. Available from: https://www.arsmedica.cl/index.php/med/article/ view/109/315.

26. Miní E, Medina J, Peralta V, Rojas L, Butron J, Gutiérrez EL. Programa de residentado médico: percepciones de los médicos residentes en hospitales de Lima y Callao. Rev Peru Med Exp Salud Publica. 2015;32:303-10. Available from: https://www.scielosp.org/pdf/rpmesp/2015.v32n2/303-310/es.

27. Alper BS, Stevermer JJ, White DS, Ewigman BG. Answering family physicians' clinical questions using electronic medical databases. J Fam Pract. 2001;50:960-5.

28. Kamalbekova G, Kalieva M. Evidence-based medicine training: kazakhstan experience. Int J Risk Saf Med. 2015;27 Suppl 1:S95-6.

29. Canelo C, Alarcón J, Amao E, Beteta V, Monge E. Conocimientos, actitudes y prácticas de la medicina basada en evidencia en médicos asistentes y residentes e dos hospitales de Lima-Perú. Rev Med Hered. 2007;18:76-84. Available from: https://www.revistas.upch.edu.pe/index. $\mathrm{php} / \mathrm{rmh} / \mathrm{article} / \mathrm{view} / 934$.

30. Haug JD. Physicians' preferences for information sources: a meta-analytic study. Bull Med Libr Assoc. 1997;85:223-32.

31. Sierra-Galán R. El idioma "inglés" en la medicina. Arch Cardiol M. 2016;86:97-8. Available from: http://www.scielo.org.mx/scielo.php?pi$\mathrm{d}=$ S1405-99402016000100097\&script=sci_arttext\&tlng=pt.

32. Álvarez M, Dennis R, Villar C. Características de estudios publicados en áreas del conocimiento de medicina interna incluyendo calidad, idioma y década de publicación. Acta Med Colomb. 2015;40:194-201. Available from: http://www.scielo.org.co/scielo.php?script=sci_abstract\&pi$d=S 0120-24482015000300005$.

33. Mejía C, Cáceres O, Vera C, Nizama A, Curioso W, Mayta P. Uso de fuentes de información en médicos recién graduados de Lima. Rev Peru Med Exp Salud Publica. 2014;31:716-20. Available from: http://www. scielo.org.pe/scielo.php?pid=S1726-46342014000400016\&script=sci_arttext. 


\section{Annex}

\section{Information Survey}

1. How many patients or cases did you attend yesterday?

2. How many questions were raised about the cases of that day?

3. How many questions made you look for an answer?

4. Why did not you look for an answer for the others?

1.

2.

3.

5. You searched for answers in:
a. Texts
b. Articles
c. Interconsultations
d. Ask the tutor
e. Internet
f. Other

6. When you use the internet, what resources do you know:

a. Google

b. MD Consult

c. Journals online

d. Medline

e. eMedicine

f. Clinical guides

g. OVID

h. UpToDate

i. Cochrane library

j. Trip database

k. Clinical evidence

I. Bandolier

m. Best Bets

n. Hinari

o. PubMed

p. EBSCO

q. Other

7. When you search on the internet, what obstacles do you encounter?

In your opinion, answer the following questions as accurately as possible:

8. What percentage of your clinical practice is based on evidence?

9. What percentage of your teacher's practice is based on evidence? 